\title{
Analisis Putusan Pengadilan Agama Terhadap Cerai Gugat dan Cerai Talak Menurut UU Nomor 1/1974 Tentang Perkawinan dan KHI
}

\author{
Mohammad Junaidi Abdillah \\ Institut Agama Islam Negeri Kudus \\ abdillahjunaidi882@gmail.com
}

\begin{abstract}
Abstrak
That this writing deals with divorce law status, either bain sughro divorce or bain kubro divorce. Seen from UU number 1 your 1974. Based on the Islamic law Regulation (KHI) explains that in verse 113 states the marriage is broken when. First by death proven by the legal administration letter (by village chief). Second the divorce can only be proven by the divorce certificate in the form of court decision, either fairners, divorce decision, taklik divorce decision or khuluk divorce. So that in the verse 38 UU number 1 year 1974 about marriage stated that the marriage is broken because of the death, divorce and the court decision. From here, the writer is interested to analyze to what extent the requested divorce case talak divorce in order to be a permanent law power. The character of a judge in conducting the duty, definitely match to the legal Indonesian law mechanism. It means, the judge must be hovest, fair and doesn't stand for either side. Qodi or a jude must be acceptable by the whole people in the various level, thus the law be come the social manipulation. There fone, there is a case brought to the court either from the suer or the sued in taking the decision must have used the law procedur based on the fifth principel, social justice for all. The law frame work is match with UUD 1945 amandement, through the institution that towards the God Almighty. So all of the decision has the permanent law power. But, in the apostle dynasty or empire. In taking the decision was fully emplaying the $A l Q u r^{\prime} a n$ and Hadits based law, continued to ijma and qiyas by the religion expert.
\end{abstract}

Keywords: Cerai gugat, Cerai talak, Khulu' UU nomor 1/1974, Kompilasi Hukum Islam

\begin{abstract}
Abstrak
Bahwasanya tulisan ini membahas tentang status hukum perceraian, baik talak bain sughro maupun talak bain kubro. Di tinjau dari undang-undang No. 1 Tahun 1974. Sebagai mana dalam ketentuan hukum Islam (KHI) di atas menjelaskan pada pasal 113, bahwasanya perkawinan dapat putus apabila: Pertama, karena kematian di buktikan dengan surat keterangan kematian dari pejabat yang berwenang (lurah atau kepala desa).Kedua, percerain yang hanya dapat dibuktikan dengan surat cerai berupa putusan pengadilan, baik berupa putusan peradilan, baik berupa putusan perceraian, ikrar, talak, khuluk atau putusan taklik talak. Sehingga dalam pasal 38 Undang-undang Nomor 1 Tahun 1974 tentang perkawinan di sebutkan bahwa putusnya perkawinan dapat terjadi karena salah satu pihak meninggal dunia, karena perceraian dan karena adanya
\end{abstract}


putusan pengadilan. Berangkat dari sinilah penulis tertarik untuk menganalisis sejauh mana putusan pengadilan agama untuk menetapkan putusannya, dalam kasus cerai gugat dan cerai talak sehingga bisa berkekuatan hukum tetap.Karakteristik seorang hakim ketika me njalankan amanah, tentunya sudah sesuai dengan mekanisme hukum yang berlaku di Indonesia. Artinya hakim harus bertindak yang jujur, adil dan tidak memihak satu sama lainnya. Qodi atau Hakim harus bisa di terima seluruh lapisan golongan masyarakat, karenanya hukum sebagai rekayasa sosial masyarakat. Sehingga apabila ada salah satu yang berperkara di meja hijau baik dari para Pemohon ataupun Termohon dalam menjalankan amar putusannya sudah tentu menggunakan prosedur hukum yang ada sesuai dengan sila ke lima, keadilan social bagi seluruh rakyat Indonesia. Landasan dasar hukum ini sudah sesuai dengan amandemen UU dasar 1945, melalui institusi yang berkeadilan kepada Tuhan YME. Sehingga kesemua putusannya bisa berkekuatan hukum tetap. Namun pada dinasti atau zaman kenabian, Apabila di dalam memutuskan perkara kesemuanya menggunakan dasar hukum Al Qur'an atau Hadits di teruskan dengan ijma' dan qiyas oleh para ulama'.

Kata Kunci: Cerai gugat, Cerai talak, Khulu' UU nomor 1/1974, Kompilasi Hukum Islam

\section{PENDAHULUAN}

Perkawinan merupakan Sunnatullah, yang mewajibkan kepada hambanya untuk berpasang-pasangan dalam kehidupannya. Dan bila mampu maka kawinilah satu,dua,tiga dan empat orang yang kamu senangi. Apabila tidak mampu maka berpuasalah karena itu bisa menahan sahwatnya. Sesuai dengan pasal 38 Undang-undang Nomor 1 Tahun 1974 tentang perkawinan di sebutkan bahwa putusnya perkawinan dapat terjadi karena salah satu pihak meninggal dunia, karena perceraian dan karena adanya putusan pengadilan. Berangkat dari sinilah penulis tertarik untuk menganalisis sejauh mana putusan pengadilan agama untuk menentapkan putusannya, dalam kasus cerai gugat dan cerai talak sehingga bisa berkekuatan hukum tetap. (pasal 38 Undang-undang Nomor 1 Tahun 1974).

Bahwa tujuan perkawinan adalah, membentuk keluarga yang Sakinah Mawaddah Warohmah, Barokah dan bahagia sejahtera. Perlunya ada keterbukan antara suami dan istri, sehingga tidak akan terjadi mis comunikation. Namun seiring perjalanannya waktu ada ketidak sinergian di dalam membentuk bahtera keluarga yang seharusnya harmonis tapi malah sebaliknya disebabkan oleh adanya ketidak percayaan antara suami dan istri sehingga jalur terakhir yang di tempuh adalah di selesaikan di pengadilan. 
Penulis meneliti bahwa di dalam putusan amarnya perkawinan karena perceraian ada dua istilah, yaitu: Cerai Gugat dan Cerai Talak. Sebagaimana dalam Kompilasi Hukum Islam pasal 114 dijelaskan bahwa perceraian yang diputuskan atas inisiatif suami disebut "cerai talak" sedangkan perceraian yang di tetapkan atas gugatan isteri disebut "cerai gugat"

\section{a. Hukum Islam memberikan hak cerai kepada isteri.}

Istilah khuluk ini dijelaskan dalam fiqh klasik dimaknai sebagai perceraian atas inisiatif pihak isteri, yang diajukan oleh isteri kepada suami dengan beberapa alasan-alasan tertentu dengan cara menyerahkan kembali mahar yang pernah diterima pada waktu menikah sebagai tebusan iwadh baik sebagian maupun seluruhnya dan suami dapat menerimanya kembali.

Isteri memiliki kesamaan hak dengan suami untuk mengajukan tuntutan perceraian. Tuntutan perceraian yang diajukan dapat dinyatakan sah oleh hakim jika dilakuan dihadapan pengadilan. Pihak yang ingin melakukan perceraian harus mengajukan gugatan perceraian ke Pengadilan. Hal ini sesuai dengan ketentuan Pasal 39 ayat (1) UU No. 1 Th. 1974 yang menentukan bahwa "Perceraian hanya dapat dilakukan di depan sidang Pengadilan, setelah Pengadilan yang bersangkutan berusaha dan tidak berhasil mendamaikan kedua belah pihak". (Pasal 39 ayat (1) UU No. 1 Th. 1974).

Perceraian harus dilakukan di depan sidang Pengadilan, sematamata ditujukan demi kepastian hukum dari perceraian itu sendiri. Seperti diketahui bahwa putusan yang berasal dari lembaga peradilan mempunyai kepastian hukum yang kuat, dan bersifat mengikat para pihak yang disebutkan dalam putusan itu. Dengan adanya sifat yang mengikat ini, maka para pihak yang tidak mentaati putusan Pengadilan dapat dituntut sesuai dengan hukum yang berlaku.

Perceraian dalam pengertian cerai gugat, yaitu perceraian yang diajukan gugatan cerainya oleh dan atas inisiatif isteri kepada Pengadilan Agama yang dianggap terjadi dan berlaku beserta segala akibat hukumnya sejak jatuhnya putusan Pengadilan Agama yang telah mempunyai kekuatan hukum tetap.

Berdasarkan pengertian dari cerai gugat di atas, berarti cerai gugat itu sendiri bisa disamakan dan masuk kepada $k h u l u$ '. Jika seperti itu adanya maka khulu' itu sendiri adalah perceraian yang terjadi atas permintaan isteri dengan memberikan iwadh atau tebusan kepada dan atas persetujuan suami.

Di dalam bunyi amar putusan terdapat perbedaan mengenai iwadh, ada yang mengharuskan iwadh dan tidak. Jika dalam bunyi putusannya jatuh talak bain sughra maka tanpa adanya iwadh, sedangkan pada bunyi putusan jatuh talak satu khul'i maka terdapat iwadh. 
Menurut hemat penulis bahwa, jatuhnya talak bain sughra dikarenakan terjadinya perselisihan dan pertengkaran (faktornya bisa dikarenakan perselingkuhan), suami ringan tangan/KDRT, atau suami tidak memberi nafkah. Jadi intinya adalah menimbulkan konflik pertengkaran.

Dalam pasal 38 UU Nomor 1 Tahun 1974 perkawinan disebutkan bahwa putusnya perkawinan dapat terjadi karena salah satu pihak meninggal dunia, karena perceraian dan karena adanya putusan pengadilan. Kemudian dalam pasal 39 ayat (2) di tentukan bahwa untuk melaksanakan perceraian harus cukup alasan yaitu antara suami istri tidak akan hidup sebagai suami istri. Ketentuan ini di pertegas lagi dalam penjelasan pasal 39 ayat (2) tersebut dan pasal 19 Peraturan pemerintah Nomor 9 tahun 1975 yang mana di sebutkan bahwa alasan yang dapat di pergunakan untuk melaksanakan perceraian adalah: (Pasal 38 UU Nomor 1 Tahun 1974).

1. Salah satu pihak berbuat zina atau pemabuk, pemadat dan lain sebagainya yang sukar di sembuhkan.

2. Salah satu pihak meninggalkan pihak yang lain dan tanpa alasan yang sah atau karena hal lain di luar kemauannya.

3. Salah satu pihak melakukan kekejaman atau penganiayaan berat yang membahayakan pihak lain.

4. Salah satu pihak mendapat cacat badan atau penyakit yang menyebabkan tidak dapat menjalankan kewajibannya sebagai suami isteri.

5. Antara suami isteri terus-menerus terjadi perselisihan dan pertengkaran dan tidak ada harapan akan hidup rukun lagi dalam rumah tangga.

Ulama fiqh juga berbeda pendapat tentang keharusan membayar iwadh. Ulama Mazhab Maliki mendefinisikan khuluk dengan "talak dengan ganti rugi, baik datangnya dari istri maupun dari wali dan orang lain". Artinya, aspek ganti rugi sangat menentukan akad ini di samping lafal khuluk itu sendiri menghendaki terjadinya perpisahan suami istri tersebut dengan ganti rugi. Menurut mereka, apabila lafal yang digunakan adalah lafal talak, maka harus disebutkan ganti rugi. Apabila yang digunakan adalah lafal khuluk maka tidak perlu disebutkan ganti rugi, karena lafal khuluk sudah mengandung pengertian ganti rugi. (Ensiklopedi Hukum Islam, Jiiid 3)

Menurut Hanafi, Malikiyyah dan dalam satu riwayat madzhab Hanbali berpendapat, khuluk terjadi dengan tanpa iwadh. Sedangkan pendapat yang rajih menurut madzhab Hanbali adalah sesungguhnya iwadh adalah rukun khuluk. Jika suami mengkhuluk isterinya dengan tanpa iwadh tidak jatuh khuluk dan tidak jatuh pula talak, kecuali jika khuluk diucapkan dengan lafadh talak, maka jatuhlah talak raj'i. Dalam 
kaitan ini para ulama telah mendiskusikan masalah perceraian yang dijatuhkan hakim akibat menghilangnya suami (giyabu al zauj) atau menjalani hukuman penjara yang dapat memberatkan isteri, dalam hal ini terdapat perbedaan pendapat antara para ulama.

Menurut ulama Hanafiyah, Syafiiyah, dan Zahiriyah bahwa isteri tidak berhak menuntut cerai karena sebab hilangnya suami atau dipenjara yang dapat memadharatkan isteri sekalipun hilangnya suami dengan uzur atau tanpa uzur.

Sedangkan menurut madzhab Syafi'i, bahwa khulu' tidak sah kecuali harus memakai 'iwadl karena khuluk itu ialah perpisahan antara suami isteri dengan iwadh dan dengan lafadh talak atau khuluk. Seperti ucapan seorang suami kepada isterinya, "aku talak kamu atau aku khuluk kamu berdasarkan ini".

\section{b. Pandangan KHI terhadap cerai gugat}

Dalam konteks hukum Islam yang terdapat dalam (KHI) istilah cerai gugat berbeda dengan yang terdapat dalam UUP maupun PP 9/1975. Jika dalam UUP dan PP 9/1975 dikatakan bahwa gugatan cerai dapat diajukan oleh suami atau istri, mengenai gugatan cerai menurut KHI adalah gugatan yang diajukan oleh istri sebagaimana yang terdapat dalam pasal 132 ayat (1)

"Gugatan perceraian diajukan oleh istri atau kuasanya pada Pengadilan Agama yang daerah hukumnya mewilayahi tempat tinggal penggugat kecuali istri meninggalkan tempat kediaman tanpa izin suami."

Mengenai hal ini, imam Malik, Syafi'i, dan segolongan fuqaha berpendapat bahwa seorang isteri boleh melakukan khulu' dengan memberikan harta yang lebih banyak dari mahar yang diterimanya dari suaminya jika kedurhakaan datang dari pihaknya, atau memberikan yang sebanding dengan mahar atau lebih sedikit.

Dalam persyaratan iwadh yang telah dijelaskan di atas, memang terjadi perbedaan pendapat antara ulama fiqh, yang membedakannya adalah jika si isteri sudah tidak kuat dan tidak sanggup lagi mempertahankan rumah tangganya yang disebabkan oleh ulah si suami, maka iwadh bukan menjadi suatu keabsahan dalam khulu'.

Uniknya di dalam surat putusan pengadilan khususnya pada isi dari alasan isteri mengajukan cerai ialah sudah tidak ada lagi keharmonisan dalam rumah tangga yang disebabkan oleh ulah suami, baik itu dalam putusan yang menjatuhkan talak satu bain sughra dan talak satu khul'i. Jika pengadilan merujuk pada pendapat ulama di atas, maka keabsahan dari khulu' adalah dengan membayar iwadh.

Perceraian dengan jalan khulu' juga merupakan tata cara khusus yang diatur dalam pasal 1 huruf i,8,124,131,148,155,161,dan 163 perceraian dengan khuluk karena pelanggaran taklik talak maka penyelesaiannya dilakukan dengan tata cara cerai gugat. 
Pada kenyataannya terdapat perbedaan dalam amar putusan pengadilan tentang cerai gugat. Adapun putusan Pengadilan Agama terkait putusnya perkawinan karena cerai gugat dalam amar putusannya berbunyi: "Menjatuhkan talak satu bain sughra tergugat (fulan bin fulan) terhadap penggugat (fulanah binti fulan)", serta "Menjatuhkan talak satu khul'i dengan iwadh sebesar..". Bahwasanya hukum adalah seperangkat aturan social masyarakat, yang di dalamnya terdapat nilai-nilai keadilan dan kedisiplinan. Jika di dalam prosedur hakim untuk memutuskan perkara ada beberapa cara bagi pengadilan untuk menyelesaikan sebuah perkara, sebagaimana di gambarkan oleh Hasbi Ash Shiddiqy dalam bukunya, Peradilan dan Hukum Acara Islam (Ash Shiddiqy, Hasbi, hal. 58-60).

\section{c. Pandangan KHI terhadap taklik talak}

Pernikahan atau perkawinan sebagaimana yang tercantum dalam pasal 1 Undang Undang Nomor 1 Tahun 1974 Tentang perkawinan yang menyatakan bahwa "Perkawinan merupakan ikatan lahir batin antara seorang pria dengan seorang wanita sebagai suami isteri dengan tujuan membentuk suatu keluarga (rumah tangga) yang bahagia dan kekal berdasarkan Ketuhanan Yang Maha Esa".

Taklik talak adalah perjanjian yang di ucapkan calon mempelai pria setelah akad nikah yang di cantumkan dalam akta nikah yang berupa janji taklik talak yang di gantungkan pada suatu keadaan tertentu yang mungkin terjadi di masa yang akan datang (KHI pasal 1 huruf e). Sighat taklik talak ini terdapat pada buku nikah bagian belakang. Pada umumnya setelah ijab kabul selesai mempelai laki-laki di minta untuk membacanya. Isi taklik talak tersebut adalah:

1) Meninggalkan istri selama 2 (dua) tahun berturut-turut;

2) Tidak memberi nafkah wajib kepadanya 3 (bulan) lamanya;

3) Menyakiti jasmani istri; dan

4) Membiarkan (tidak memperdulikan) istri selama 6 (enam) bulan atau lebih.

Sesuai ketentuan pasal 39 ayat (2) Undang-undang Nomor 1 Tahun 1974 tentang

Perkawinan Pasal 19 huruf (f) Peraturan Pemerintah Nomor 9 Tahun 1975 jo pasal 116 huruf (f) Kompilasi Hukum Islam. Permohonan untuk menjatuhkan talak kepada istri dapat di kabulkan dengan verstek. Talak yang di jatuhkan suami adalah talak satu roj'I terhadap istri (Termohon) yang di putuskan oleh Pengadilan Agama.

Pemohon atau termohon dalam hal ini adalah seorang suami yang bermaksud menceraikan istrinya haruslah terlebih dahulu mengajukan permohonan kepada Pengadilan Agama. Permohonannya harus di tujukan kepada pengadilan Agama yang mewilayahi kediaman istrinya. Apabila istrinya dengan sengaja dan tanpa izin suaminya telah 
meninggalkan tempat kediaman yang di sepakati, permohonan tersebut diajukan pada Pengadilan Agama yang mewilayahi tempat kediaman suami. Begitu pula jika suami istri tersebut (keduanya) bertempat tinggal di luar negeri, maka permohonan diajukan kepada Pengadilan Agama yang mewilayahi tempat di langsungkannya pernikahan mereka dahulu, atau boleh juga kepada Pengadilan Agama Jakarta Pusat.

Di dalam pengajuan permohonannya bersifat tertulis kepada Pengadilan Agama yang bersangkutan. Dan bagi orang yang tidak dapat menulis, boleh mengajukannya secara lisan. Dengan persyaratan, permohonan harus di cantumkan atau di sebutkan nama, umur, tempat kediaman suami dan istri dan menjelaskan alasan-alasan yang di jadikan dasar cerai talak.

Hukum Islam telah mengatur sedemikian rupa hubungan suami istri. Keduanya di perintahkan untuk sedapat mungkin dan dalam batasbatas kemampuan mereka supaya membina suatu rumah tangga dalam suasana yang penuh dengan rahmah, mawaddah (kasih sayang) dan sakinah (ketenteraman). Namun, apabila salah satu pihak atau keduanya tidak mungkin lagi mewujudkan ketiga prinsip itu, maka Hukum Islam, demi kemaslahatan mereka bersama telah membuka pintu (darurat) untuk menyelesaikan sengketa rumah tangga itu melalui suatu perceraian.

Penyelesaian ini merupakan jalan terakhir setelah di tempuh jalan perdamaian, atau (islah) antara suami istri, yaitu untuk bisa rukun kembali.

Menurut versi penulis apabila jalur perdamaian ini yang ditempuh tertutup, maka antara suami atau istri hendaklah menempuh jalur yang arif dan bijaksana lagi, sehingga di mungkinkan adanya keterbukaan antara kedua belah pihak ini, Secara hukum apabila istri yang baru di talak satu (menurut versi istri) dihadapan pejabat yang berwenang adalah tidak sah. Karena perceraian hanya dapat dilakukan disidang pengadilan setelah pengadilan yang bersangkutan berusaha dan tidak berhasil mendamaikan kedua belah pihak, sebagaimana ketentuan dalam Kompilasi Hukum Islam (KHI) pasal 113, bahwasanya perkawinan dapat putus karena dua hal:

Pertama, karena kematian di buktikan dengan surat keterangan kematian dari pejabat yang berwenang (lurah atau kepala desa).

Kedua, perceraian yang hanya dapat dibuktikan dengan surat cerai berupa putusan pengadilan, baik berupa putusan perceraian, ikrar talak, khuluk atau putusan taklik talak. Kemudian di dalam teori (Joel Feinberg), di jelaskan bahwa: Pemberian hak penuh merupakan kesatuan dari klaim yang absah (keuntungan yang didapat dari pelaksanaan hak yang disertai pelaksanaan kewajiban). 
Di sini berarti antara hak dan kewajiban tidak dapat saling dipisahkan. Oleh karena itu, ketika seseorang menuntut hak, juga harus melakukan kewajiban. Meskipun hak dan kewajiban ini adalah sesuatu yang tidak dapat dipisahkan, akan tetapi sering terjadi pertentangan yang sangat hebat di keluarga, Karena hak dan kewajiban tidak seimbang. Sudah sangat jelas bahwa setiap warga negara (Indonesia) memiliki hak dan kewajiban untuk mendapatkan penghidupan yang layak, akan tetapi pada kenyataannya masih banyak saudara-saudara kita yang memilih jalur atau jalan yang di larang dan dibenci oleh agama yaitu dengan perceraian.

Ketika salah seorang sahabat utama Rasulullah SAW, yaitu Umar bin Khattab tidak mungkin mau melakukan suatu perbuatan yang menyimpang dari sunnah Rasulullah SAW dan Sayyidina Abbas sendiri yang meriwayat hadits di atas, dalam keterangan yang lain berpendapat talaq tiga sekaligus jatuh tiga, maka pengertian talaq tiga pada hadits di atas, yang lebih tepat dan lebih sesuai dengan derajat seorang Umar bin Khatab adalah bahwa pada zaman Rasulullah SAW, Abu Bakar dan dua tahun masa khalifah Umar bin Khatab, talaq yang dijatuhkan tiga kali berulang-ulang dalam suatu tempat kepada seorang isteri, seperti seorang laki-laki berkata : "Aku talaq engkau, Aku talaq engkau, Aku talaq engkau" , sedangkan suami yang mengatakan kalimat talaq itu, tidak meniatkan sebagai ta'kit (penguatan) dan tidak juga sebagai isti'naf (mengucapkan kalimat bukan sebagai penguatan), maka ditetapkan sebagai talaq satu, karena kalimat kedua dan ketiga, banyak penggunaannya pada masa itu sebagai ta'kid dan sedikit penggunaannya sebagai isti'naf. Sedangkan pada zaman Umar, kalimat kedua dan ketiga tersebut banyak penggunaannya sebagai isti'naf, maka ditetapkan pada masa itu, jatuh talaq tiga apabila diucapkan tanpa niat apa-apa (mutlaq), karena pertimbangan kebiasaan pada masa itu. Pengertian ini lebih shahih menurut Imam an-Nawawi. (Imam an-Nawawi, Syarah Muslim)

Seperti yang telah Allah janjikan kepada umat-umatnya: "Sesungguhnya jika kamu bersyukur pasti kami akan menambah (nikmat) kepadamu, dan jika kamu mengingkari (nikmat-Ku), maka sesungguhnya azab-Ku sangat pedih." (QS. Ibrahim [14: 7])

Sudah jelas dikatakan bahwasanya ketika seorang yang mau mensyukuri nikmat-nikmatnya maka Allah SWT akan menambahkan, begitu juga sebaliknya apabila mengingkari maka azab-Ku sangatlah pedih.

Keluarga terdiri dari ayah,ibu, dan anak-anak. maka dalam membentuk keluarga yang bahagia dan sejahtera perlu di landasi dengan iman,taqwa sehingga terciptalah kedamaian. Memang tidaklah mudah akan tetapi jika ada niat dibarengi dengan (ibadah), tercerminlah ketulusan hati, sebagai insan yang sabar tawakkal di barengi dengan adab 
atau budaya yang mana disitu bisa menjunjung tinggi nilai-nilai moralitas antara satu sama yang lainnya. Terutama dalam konteks ini dengan menghargai antara kedua belah pihak (suami atau istri), serasa menjaga keutuhan bersama demi keutuhan keluarga, Negara dan Bangsa.

Semua itu akan terlaksana apabila masing-masing tau akan tanggung jawab Suami atau istri, yang haruslah mampu menjaga kewajiban keluarganya . Jika keadaannya seperti ini, maka semua akan berjalan dengan baik. dan oleh karenanya apabila tidak ada keseimbangan antara hak dan kewajiban, maka kesemuanya bisa terjadi konflik horisontal. Untuk mencapai keseimbangan antara hak dan kewajiban, dalam hal ini hak dan kewajiban haruslah direalisasikan tanpa harus diberi tahu terlebih dulu. Bahwasanya hal ini merupakan modal bagi keutuhan keluarga, utamanya adalah suami dan istri. Kemudian anakanak adalah asset bagi orang tua, yang wajib dijaga, dibina demi keutuhan keluarga untuk mencerdaskan kehidupan yang abadi berdasarkan pada pancasila dan UUD 1945.

\section{KESIMPULAN}

Undang-undang perkawinan di Indonesia baik melalui UndangUndang no. 1 tahun 1974 Tentang perkawinan dan Kompilasi Hukum Islam Inpres no. 1 tahun 1999 membedakan antara perceraian atas kehendak suami disebut cerai talak dengan perceraian atas kehendak istri disebut cerai gugat atau khulu'. Adapun mengenai alasan-alasan cerai gugat UUP pasal 39 Jo. Pasal 19 Peraturan pemerintah no. 9 tahun 1975 tentang pelaksanaan UUP dan KHI pasal 116 menyebutkan pada poin $g$ diantaranya adalah Suami melanggar ta'lik talak. Berkaitan dengan hal tersebut, Kompilasi Hukum Islam, jelasnya mempunyai alasan tersendiri mengapa cerai gugat yang ada di Indonesia memiliki perbedaan dengan fiqh klasik.

Dalam KHI Pihak isteri (penggugat) bisa memilih alasan perceraian melalui cerai gugat sesuai dengan yang dialaminya. Alasan ini bisa dikarenakan perselingkuhan, pertengkaran, KDRT serta bisa juga dikarenakan pelanggaran taklik talak. Nantinya proses hukum serta akibat hukum yang berlaku akan berbeda sesuai dengan alasan yang diajukan oleh pihak isteri (penggugat).

Terkhusus lagi, dalam kajian ini mengenai cerai gugat dengan menganalisis putusan hakim yang mempunyai dua bentuk putusan dalam penetapannya yaitu talak bain sughra cerai gugat dan talak satu khul'i. Sifat atau keadaan bagaimana yang dijadikan sebagai dasar penetapan hukum, sehingga pengadilan agama dalam amar putusannya menjatuhkan talak satu bain sughra dan talak satu khul'i terkait perkara cerai gugat. 
Salah satu putusan Pengadilan Agama dalam memeriksa dan mengadili perkara perceraian tentang cerai gugat karena alasan suami melanggar taklik talak. Bagaimana putusan hakim dan apa yang menjadi dasar pertimbangan hakim dalam putusannya tersebut. Berdasarkan bentuknya telah memenuhi syarat formil sebuah putusan meliputi Kepala putusan, Identitas pihak-pihak yang berperkara, Ringkasan gugatan, Petitum, Amar putusan (diktum), dan keterangan lainnya, jenis putusannya merupakan putusan verstek.

\section{DAFTAR PUSTAKA}

al-Jaziri, Abdur Rahman, Kitab al-Fiqh 'ala Madzahib al-Arba'ah, Beirut: Dar al-Kutub al-ilmiyah, 2003 M, IV.

Ash-Siddieqy, Nourouzzaman, Peradilan dan Hukum Acara Islam, Fikih Indonesia :Penggagas dan Gagasannya, Yogyakarta: Pustaka Pelajar, 1997.

Az-Zuhaili, Wahbah, Fiqhul Islam wa Adillatuhu, Damaskus: Dar al-Fikr, 1985.

Cerai gugat : 493 perkara 2015.

Cerai talak : 180 perkara

Ensiklopedi Hukum Islam, Jiiid 3, PT ICHTIAR BARU VAN HOEVE, Jakarta, Cet.ke7,

Imam an-Nawawi, Syarah Muslim, Dar Ihya al-Turatsi al-Arabi, Beirut, Juz. X,

Imam an-Nawawi, Syarah Muslim, Dar Ihya al-Turatsi al-Arabi, Beirut, Juz. X, 2006

KHI Pasal 1 ayat $\mathrm{i}$

Muhammad al Khatib al Syarbini, Mughni al Muhtaj 'ala Ma'rifati Ma'ani al Faz al Minhaj, Mesir: al Maktabah al Tijariyah, tt..

Muhammad bin Idris al Syafi'I, al-Umm, Beirut:Daar al-Fikr, tt.

Muhammad Saifullah, Mohammad Arifin, Ahmad Izzuddin, Hukum Islam solusi permasalahan keluarga, Semarang: UII Press Yogyakarta 2005

oleh para ulama'.

Pasal 38 Undang-undang Nomor 1 Tahun 1974.

Pasal 39 ayat (2) Undang-undang Nomor 1 Tahun 1974 tentang Perkawinan Pasal 19 huruf (f).

PP No 9 Tahun 1975 jo pasal 116 huruf (f) Kompilasi Hukum Islam.

Sayyid Sabiq, Fiqhus Sunnah, Baerut : Dar al-Fikr, Juz 3, t.t

Syaifuddin, Muhammad dkk, Hukum Perkawinan, Jakarta: Sinar Grafika, 2014. 